\title{
19. Yüzyılın Son Çeyreğinde Osmanlı Mahkemelerinde Vasi
}

\section{Tayini}

\section{Seda Saraç Özturan}

\section{Özet}

Inceleyeceğimiz makale Osmanlı hukuk yapısı çerçevesinde şekillenmiş mahkeme kayıtları içerisindeki bir sicil defterinde yer alan vasî / hukuki temsilci davalarıdır. Bu davalardan; Vasîlik ile ilgili konuların hangi nedenlerle ele alındığını, böyle bir durumun ortaya çıkmasında etkili olan durumları, vasîliğin ne demek olduğunu, hukuki temsilci olarak vasî'nin yükümlülükleri ve sınırları, vasî atanan kişilerin hak ve sorumluluklarının neler olduğu ya da olabileceği incelenmektedir.

Ayrıca Osmanlı hukuk yapısında gerçekleşen değişimlerin/ düzenlemelerin mahkeme kayıtlarına yansıma şekilleri ile Osmanlı toplum yapısında ortaya çıkan değişim ve gelişmeler üzerinde durulmuştur.

Anahtar Kelimeler : Şer'iyye Sicil Kaydı, Hüccet defteri, Vasî, Hukuki Temsilci, Vasîlik.

\section{Guardian Assignment in the Ottoman Courts in the Last Cuarter of the 19th Century}

\section{Abstract}

The article we will examine is case law / legal representatives in a record book in court records formed in the frame of Ottoman legal structure. From these cases; It examines the reasons for the issue of vassal status, the conditions that are effective in the emergence of such a situation, what it means, the obligations and boundaries of the legal entity as the legal representative, and the rights and responsibilities of the persons appointed as legal representatives.

In addition, the forms of reflection of changes in Ottoman law structure to court records and changes and developments in Ottoman society structure are emphasized.

Keywords: Şer'iyye Registry Record, Hüccet Book, Guardian, Legal Representative, Guardianship.

\footnotetext{
* Yüksek Lisans Öğrencisi, Sakarya Üniversitesi, Sosyal Bilimler Enstitüsü, Tarih ABD, Yakınçağ Tarihi Bilim Dalı, sedasaracozturan@gmail.com. (Makale Gönderim Tarihi: 19.02.2018; Makale Kabul Tarihi: 03.04.2018) (ORCID ID: 0000-0002-2371-0641).
}

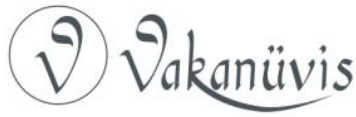




\section{Giriş}

Bu çalışmada 19. yüzyılın son on yılı ve 20. yüzyılın başlarında Osmanlı mahkemelerinde alınan vesayet kararları ile vasîlik örnekleri incelenecektir.

Çalışma içerisinde hukuki temsilci olarak vasîlik ile ilgili gerek İslami kaynaklara gerekse Osmanlı araştırmalarına katkı sağlayan araştırmacıların incelemiş olduğu kaynaklardan faydalanılmıştır. Bu kaynakların yanı sıra incelediğimiz 122 No'lu Anadolu Kazazkerliği ve Sadareti'ne ait sicil defterine yansımış bilgiler bir bütün olarak değerlendirilerek özgün bir çalışma oluşturmaya çalışılmakla birlikte bu alanda araştırma yapacak kişi ve kişilere "vasî-vasîlik" konularında bir kaynak oluşturmak hedeflenmiştir.

Çalışmaya konu olan defter, Anadolu Kazaskerliği ve Sadareti'ne bağı 122 No'lu Şer'iyye Sicil defteridir. Osmanlı mahkeme kayıtlarının konularına göre çeşitli işlevlerle olmakla birlikte hepsinin kendine özgü kuralları olması bakımından birçok türü bulunmaktadır. İncelediğimiz defter ise bu özellikler içerisinde türü bakımından bir hüccet defteridir.

Hüccet kelimesine baktığımızda "Osmanlı hukuk terminolojisinde iki anlamda kullanıldığını görmekteyiz: İlk olarak şahitlik, ikrar, yemin anlamında kullanılırken, bir diğer anlamı ile kadı huzurunda tarafların birbirlerine ikrarını, diğerinin bu ikrarının tasdikini içeren ve bir hükmü ihtiva etmeyen hususlara yönelik düzenlenmiş belgeleri ifade etmektedir." ${ }^{1}$ Tanımdan yola çıkarak hüccet defterinin, basit bir ifade ile görülen davaların bir kopyasının toplandığı defterler olduğunu söyleyebiliriz. Bu özelliği ile kuşkusuz günümüzdeki noterlerin işleyişi ile benzer bir yapıya sahip olduğu anlaşılmaktadır.

Hüccet belgelerinin şekil olarak diğer belgelerle ayrımını gerçekleştiren önemli unsur üst kısmında kadının imzası ve mührünün bulunmasıdır. Bu ayrım hüccetin orijinal olduğunun göstergesidir çünkü sicile kaydedilmiş hüccetlerde mühür ve imza yer almamaktadır.

Genellikle hüccetlerde üç bölüm vardır: 1. Davalı, 2. Davacı ve 3. Kısım bunlar arasındaki davaların yer aldığı bölümlerdir. Hüccet

\footnotetext{
${ }^{1}$ Azmi Özcan ve Diğerleri, "Hüccet”, İslam Ansiklopedisi, Cilt 18, İstanbul: Diyanet Vakfı Yayınları, 1998, s.446.
}

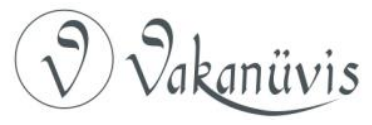


defterine kadı́nın ele aldığı her türlü dava konusu kaydedilebilmektedir. Bunlar arasında: Köle ve köle azatından, borçla ilgili konulara, nafaka, terbiye vekâletinden, vesayet ve vekâlet davalarına, gasp, cinayet, alım-satım mukaveleleri, nikâh akdi, miras, rehin- rehin kaldırma gibi davaların hepsi bu defterlerde yer almaktadır.

\section{Vasî}

Geçmiş yıllardan günümüze dek her toplum kişi - birey kavramının farklılı̆ını - çerçevesini ait olduğu coğrafyanın özelliklerine, sahip oldukları zenginliğe, ilerleme düzeyleri, inanç şekilleri, aile yapıları ile bağlantılı olarak belirlemiştir. Bir toplumun ilerleme düzeyi kişi haklarına verdiği önemi göstermesi açısından dikkatle incelenmesi gereken bir unsurdur. Birey, ailenin temel taşı olması sebebiyle kişi haklarına verilen önem aslında ailenin korunmasına da verilen önemin göstergesi olmuştur. Eski Türklerde özellikle 'Uygurlardan kalma vesikalar arasında daha o dönemlerde evlatlık müessesinin varlığını ve bu varlık çerçevesinde evlat edinen ve evlatlık veren baba arasında mukavelenin yapıldığı ve bu mukaveleye göre evlat edinilen çocuğun öz çocuklar ile eşit haklara sahip olduğu kayıtların varlığını görmekteyiz. ${ }^{3}$

Süreç Osmanlı Devleti'ne gelene dek tarih sahnesindeki pek çok devlet toplumsal bir varlık olan bireye yaklaşımlarını iyileştirmiş ve bu iyileştirmeleri farklı fikir alt yapıları ile destekleyebilmiştir. Osmanlı'da hâkim olduğu coğrafyalardaki öncül devletlerin uygulamalarından beslenmiş aynı zamanda bu uygulamaları geliştirmiştir. Bu nedenle yönetimde yer alamayan ve Osman oğulları hanedanı dışındaki Müslüman ve gayrimüslim tebaayı oluşturan her Osmanlı ferdi toplumsal yapı içerinde varlık bulmuştur. Bu nedenledir ki Osmanlı Devleti bünyesinde yer alan han, hamam, cami, medrese, kervansaray, hastane, çeşme vb. yapılar devlet tarafından değil, vakıflar aracılığıyla

\footnotetext{
2 Özcan, a.g.m., s. 446.

${ }^{3}$ Sadri Maksudi Arsal, Türk Hukuk Tarihi, Ankara: Türk Tarih Kurumu Yayınları, 2014,s.339.
}

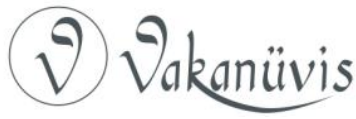


inşa edilmiş ve yönetimleri de yine vakıflarca sağlanmıştır. ${ }^{4}$ Halkın her türlü şikâyet hakkı Cuma camilerinin bulunduğu merkezi alanlarda kadı́nın ve daha uzak bölgeler için naibler aracılığıyla desteklenmiştir. Böylece Osmanlı toplumsal düzeninin sağlıklı bir dinamizmle kontrolü dengelenmeye çalışılmıştır.

Osmanlı toplumunda her bireyin şikâyet hakkı mevcuttur. Bu ister kadın, ister erkek, ister Müslüman ya da gayrimüslim olması fark eden bir durum değildir. Aslında Osmanlı kadınının yeri ve önemi hakkında çok detaylı bilgiler olmadığı hatta bu konudaki araştırmaların ancak 1970 'li yıllarda Jennings ve 1980 'li yıllarda Haim Garber, Abraham Marcus, Afif Marsot, Judith Tucker ve Suraiga Faroghi ${ }^{5}$ ile başlayarak devam eden araştırmalardan ulaşılmaktadır. Veriler kadınların yaptırmış olduğu vakıfların diğer vakıflar içerisinde yüzde yirmi gibi bir orana tekabül ettiğini göstermektedir. Bu veri Osmanlı Sosyal devlet anlayışını vurgulaması hem de kadınlara böyle bir alanda varlık gösterebilme imkânlarını sunması açısından önem teşkil etmektedir.

Osmanlı sosyal düzeni ile ilgili önemli bir göstergede çocuklar ile ilgili yapılmış düzenlemelerdir. Bu düzenlemelerden hiç kuşkusuz en önemlisi 19. Yüzyıl'ın ikinci yarısına tekabül eden tarihte çıkarılmış bir kanun düzenlemesi olan eytam sandıklarıdır. Eytam sandıklarının çıkış noktası vefat eden ebeveynlerinden yetimlerine intikal edecek malların zayi edilmeden, sağlıklı bir şekilde muhafaza edilerek rüşd yaşına dek ( hukuki olarak malları üzerinde tasarruf etme yaşa geldiğinde) sahibine ulaştırılması anlayış ve sorumluluğu yatmaktadır. ${ }^{6}$ Bu dönem Osmanlı devlet düzeni ve toplumsal yapı dinamiklerinde pek çok değişimin yaşandığı bir süreçtir. Fakat eytam sandıkları düzenlemesinin yanı sıra bu tarihe kadar eytam sandıklarının yerine getirdiği işlemler vasîler aracılığıyla gerçekleştirilmiş ve gerçekleştirilmeye de devam edilmiştir.

\footnotetext{
${ }^{4}$ Hasan Yücel, "Osmanlı Devleti'nde Vakıflar ve Kadın (16. ve 17. Yüzyıllar)", Osmanlı, 5.Cilt, Edt: Hasan Celal Güzel, Güler Eren, Yeni Türkiye Yayınları, Ankara 1999-2004, s. 49.

${ }^{5}$ Betül İşpirli Argıt, "Osmanlı Hukuk Çalışmaları’nda Kadın", Türkiye Araştırmaları Literatür Dergisi, Cilt:3, Sayı:5, 2005, s. 577.

${ }^{6}$ Tahsin Özcan, Osmanlı Toplumu'nda Yetimlerin Himayesi ve Eytam Sandıkları, iü ilahiyat Fakultesi Yayınları, İstanbul 2006, Sayı:14, s. 106.
}

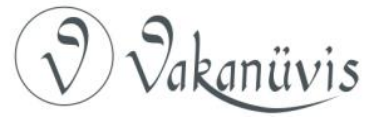


Böyle kurallar ve düzenlemelerle Osmanlı toplum kurallarının merkezinde yer alan ve en küçük yapı olan "birey" haklarının korunması - gözetilmesi anlayışı vasî kavramının varlığını teşkil etmiştir. Terminolojik olarak vasî kavramı "Velayet altında bulunmayan küçüklük, ihtiyarlık gibi sebeplerle kısıtlılığı ifade ederek medeni haklarını kullanmaktan mahrum olan kişilerin menfaatlerini korumak üzere mahkeme tarafından tayin edilmiş kanuni temsilciyi" ${ }^{7}$ ifade eden kavramdır.

Vasî'nin kimlere atandığı kısmına gelince burada kuşkusuz hukuki tanım ve tabirler devreye girmektedir. Bizim birey / kişi / şahıs tabirlerimizin karşıı̆ı̆ını hak sahibi olabilen ve borç yüklenebilen kimse ${ }^{8}$ olarak tanımlanırken ehliyet sahibi olabilme tanımı ise kişinin haklara sahip olma, bunları kullanma, borçlar ve sorumluluklar yüklenebilme yeteneğini ifade etmektedir. ${ }^{9}$ Kişilik kavramı ise gerçek ve tüzel olarak ikiye ayrılmaktadır ki bizi ilgilendiren kısım gerçek kişilik kısmıdır. Gerçek kişilik çocuğun sağ ve tam olarak doğumuyla başlayıp ölümüne kadar geçen süreci ifade eder. Gerçek kişilik de hak ehliyeti ve fiil ehliyeti olarak ikiye ayrılmaktadır: Hak ehliyeti kişinin doğuştan hak ve borçlara sahip olmasıdır. Fiil ehliyeti ise bir kimsenin kendi irade ve davranışlarıyla hukuki bir sonuç meydana getirebilmesini ifade etmektedir. Fiil ehliyetinin yerine getirilemediği durumlar ise; ayırt etme gücü ( yaş küçüklüğü, akıl hastalığı, sarhoşluk), Reşit / ergin olma, Kısıtlı / mahcur olmamadır ${ }^{10}$. İşte bu gibi durumların ortaya çıktığı hallerde kişilere Vasî tayininin zorunlu kılındığı ve bu durumun mahkeme kararı ile belirlenerek mahkeme kararı ile sonlandırıldığı durumlardır.

Vasî'nin belirlenmesinde izlenmesi gereken birinci öncelik babanın baba yok ise dedenin ve her ikisinin olmama durumunda kadının tasarrufuna kalmış bir durumdur. ${ }^{11}$ Fakat Osmanlı uygulamasında babanın olmadığı pek çok durumda yetkili vasi olarak anne tayin

\footnotetext{
${ }^{7}$ Fehmi Yılmaz, "Vasî", Osmanlı Tarihi Sözlüğü, Gökkubbe Yayınları, İstanbul: 2010, s. 680.

${ }^{8}$ Selahattin Bağdatlı, "Kişi”, Hukuk Sözlüğü, Derin Yayınları, İstanbul 2012, s. 395.

9 Bağdatlı, "Ehliyet", s. 184.

${ }^{10}$ Şaban Kayhan, Hukukun Temel Kavramları, 4. Baskı, Seçkin Yayınları, Ankara 2011, s. 72-76.

11 "Vesayet", islam Ansiklopedisi, cilt: 43.s. 67.
}

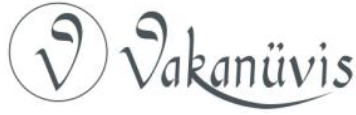


edilmiştir. ${ }^{12}$ Pek çok durumda ise kadı'ların yaptıkları vasî tayinlerinde kan bağına rastlanmamaktadır. ${ }^{13}$ Vasî olarak atanacak kişinin hür, akıl sahibi, bülûğa ermiş, reşit ve güvenilir bir kimse olması yeterli bir durumdur. Ayrıca vasî olarak atanacak kişinin vasîsi olduğu kişi ile aynı dinden olması gerekmektedir. ${ }^{14}$

Vasî’nin baba tarafından belirlendiği durumlarda vasî-i muhtar, kadı tarafından belirlenmiş olduğu durumlarda ise vasî-i mansub adını aldığını görmekteyiz.

Belgelerde vasîllerin ücret alıp almadıklarına rastlanmadığı gibi çocukların malları üzerinde yapacakları tasarruf hakkı için kadı́nın iznini almak zorundadırlar. Vasî olan kişi vasî olduğu kişilerin malları üzerinde onlar adına tasarruf edebilir fakat bunun için yine kadı́nın iznini alması gerekir. ( Bkz: dava 100/1) Vasîlerin görev süreleri ile ilgili herhangi bir bilgiye rastlanmamakla birlikte genel olarak "akil- baliğ olana dek" tabiri kullanılmaktadır ki bu tabir nedeniyle vasîliğin kaldırılma talebi ile mahkemeye başvurulduğu davalarıda görmekteyiz.

Özetle Anadolu Kazaskerliği ve Sadereti'ne bağlı 122 No'lu Şer'iyye Sicil Kaydı Hüccet defterine yansımış olan Vesayet-Vasî konulu hüccetler şahısların kendi ölümleri ya da boşanma halinde kendileri çocukları veya bıraktıkları mallar hakkında vasiyetleri kayıt altına alma, vasiyet mallarının paylaşımı, köle ve cariye azad etme, vakıflara paramülk bağışı gibi konuları içermektedir. Ayrıca vasî tayini hüccetlerinde küçük yaşta yetim kalan çocukların veraset mallarını kendilerine verilmemesinden dolayı çocuklar ergin olana dek onlara vasî tayin edilmesi ile veraset konularını içermektedir. ${ }^{15}$

Bu kapsamda 122 No'lu Şer'iyye Kaydı Hüccet Defteri'nde on tane Vasî tayini kaydı olduğunu ve bunların iki tanesi mecnunluk, iki tanesi gemi kazası sonucu miras taksimi, vasî tayini, üç tane vasî değişim talebi, biri yaş sebebiyle vasî tayinini, bir tanesi ölüm sonrası ve bir

\footnotetext{
${ }^{12}$ Mehmet Akif Aydın, Türk Hukuk Tarihi, 13. Baskı, Beta Yayınları, İstanbul 2015, s. 223.

${ }^{13}$ Nurcan Abacı, Bursa Şehri'nde Osmanlı Hukuku'nun Uygulanması (17. Yüzyıl), 1. Baskı, T.C Kültür Bakanlığı Yayınları, Ankara 2001, s. 166.

${ }^{14}$ Aydın, a.g.e., s. 223.

${ }^{15}$ Argit, a.g.e., s. 584.
}

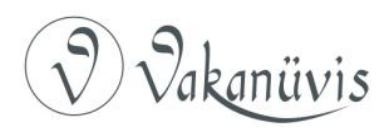


tanesi de bakamama sebebiyle Vasî tayinlerini içeren davalar yer almaktadır.

\section{İslam Hukukuna Göre Vasî}

İslam hukuku denilen tabir tarih sahnesine 610 yılında Hira'da $\mathrm{Hz}$. Muhammed'e ilk vahiy ikra "oku" emriyle nüzul etmeye başlayan Kuran-ı Kerim'in öğreti ve yaptırımlarına bağı olarak şekillenmiştir. Halifeler sonrası ardıl Müslüman devletlerin, gelişmelerine bağlı olarak olgunlaşmıştır. Fakat bu tabiri akademik anlamı ile açıklayacak olursak İslam hukuku, aslında fıkıhın bir başka ismidir. Günümüzde fıkıh bilgilerini, ibadetler gibi kişisel tarafları ağır basan hükümler ve akidler, miras, nikâh gibi ictimai tarafı ağır basan hükümler olarak ikiye ayırarak incelemek adet olmuş ve fıkıh'ın sosyal içerikli konuları İslam hukuku olarak adlandırımıştır. ${ }^{16}$ islami değerler içerisinde çocuk hakları, çocuğun öksüz - yetim halde kaldığı durumlara çok fazla önem verilmiş bizzat bu hususlar, ayetlerle koruma altına alınmıştır. Vasî gibi bir tabir İslam Hukuku içerisinde buna paralel ortaya çıkmış ve şekillenmiştir.

Tam eda ehliyetine sahip olmayan kişilerin her türlü hukuki işlemlerini kanuni temsilcileri aracılığıyla yürütülmesi olayı veli ya da vasi aracılı̆ı̆yla idare edilmektedir. Bir kimsenin velisi sırasıyla baba ve dede bunlardan sonra en yakın erkek akrabadır. Veli hür, akıl, baliğ ve çocuk ile aynı dinden olmalıdır. Bir kimsenin vasîsi ise sırasıyla baba, dede, bu ikisinin tayin ettiği vasîler bunlarda yoksa hâkimin tayin ettiği kişi vasîdir. Vasî, veli ile aynı şartları taşıması ve güvenilir bir kimse olması gerekmektedir. ${ }^{17}$. Bir başka farklılık doğuran tabir vesayet ve vekâlet arasındadır ki velayet; bir kimsenin malları üzerinde koşulsuz tasarrufu ifade eder fakat vesayet böyle bir durumu içermemekle birlikte vasî'nin tasarrufu gerektiren kısımdaki işlemleri kapsar ki bu işlemleri kanunsuz, izinsiz yapamaz. Eğer yaparsa kanunen vasîliği iptal edilirdi. Bu nedenle vesayet tabiri altında vasî olan kişi bir nevi vasîsi olduğu kişinin hukuki temsilcisi olmanın yanı sıra onun malları üzerinde onun adına tasarrufta bulunurken bunun sınırları dahi hukuken

\footnotetext{
${ }^{16}$ Ekrem Buğra Ekinci, ìslam Hukuku (Umumi ve Hususi Hükümler), İstanbul 2016, s. 33.

${ }^{17}$ Ekrem Buğra Ekinci, Osmanlı Hukuku "Adalet ve Mülk", İstanbul 2017, s. 410, 411.
}

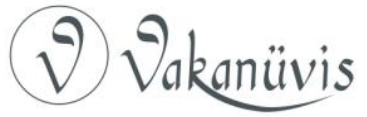


belirlenmek zorunda olup buna uygun davranabilmeyi gerektiren hukuki temsilciye verilen adlandırmadır.

\section{No'lu Defterde Vasîlik Örnekleri}

Anadolu Kazaskerliği ve Sadareti'ne bağlı 122 No'lu Şerîyye Sicil "hüccet" defteri 1308 /1309 ( M. 1890-1891) 102 varak 108 davadan oluşmaktadır. 108 dava içerisinde 10 dava vasîlik konularını kapsamaktadır. Vasîlik ile ilgili davalar rüşd isbatı, yaşlııık sebebiyle vasî tayini, ölüm sonucu vasî tayini, mecnuna vasî tayini, vasî değişim talebi ve öksüz kalan bir kız çocuğunun babasının durumu olmaması beyanıyla bir kadının yanına hizmetli olarak verilmesi ve kadının vasîsi olarak atandığı davaları içermektedir.

\section{a) Rüşd İsbatı Sebebiyle Vasî Tayini}

İncelediğimiz defterde rüşd ispatı sebebiyle üç dava yer almaktadır. Bu davalardan ilki defterimizin 15. sayfasında yer alan 1. $(15 / 1)^{18}$ davadır. Bu davada baba Nuri Bey'in ölümü ile oğul Hüseyin'in vasîsi annesi olarak belirlenmiş ve kassam tarafından 20 yaşına geldiğinde akil-baliğ ve rüsd kabul edilerek kendisine ait mirasın teslim kararı alınmıştır. Oğul Hüseyin artık müddet olarak belirlenen zamanı doldurması sebebiyle akil-baliğ ve rüşd olduğunu iddia ederek rüşdlüğünün isbatı ile miras malının kendisine devrini istemektedir. ${ }^{19}$

Dava sonucunda Hüseyin'e rüşd belgesi verilmesine şahidlerin beyanlarıyla karar verilmiştir.

Rüşd ispatı ile gerçekleşmiş ikinci davamı defterin 18 numaralı sayfasında yer alan 1. davadır. Bu davada Mehmet Akif Efendi 52

\footnotetext{
${ }^{18}$ Davalar incelenirken davaların numaraları yaprak ve sayfa özellikleri çerçevesinde belirlenmiştir. Dava numaralarında göreceğiniz sayılar örneğin 64 / 1 ifadesi 64 . sayfanın 1. davasını ifade etmektedir. 64 /2 gibi bir numaralandırma 64. sayfada iki davanın bulunduğu ve ikinci davanın başlandığını ifade eden sayıdır.

19 “Kartal Kazâsı'nda sâkin iken bundan akdem maktûlen vefât eden kazâ-i mezkûr tabur ağası Nuri Bey ibn Abdi ibn Abdurrahman'ın sağir oğlu olub Hüseyin vefatında sağîr ve el-yevm yirmi yaşını mütecâviz olduğu mahmiyye-i İstanbul'da Kapân-ı dakîk kurbünde Hızır Bey Mahallesi imamı muhtarânı tarafından i'tâ olunan bir kıtca memhûr ilmuhaber meâlinden müstebân olub ber vech-i âtî rüşdini iddi'â eden......" ( Bkz: Anadolu Kazaskerliği ve Sadareti 122 No'lu Şer'iyye Sicil Defteri, 15/1)
}

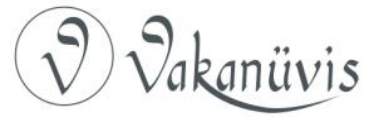


Yaşında olması sebebiyle kendisine Oğlu Ahmet Tevfik Efendi vasî olarak atanmıştır. Fakat baba rüşd ispatına giderek halen aklı başında olduğunu, kendi malları üzerinde mukaviyeti konusunda mahkemeye başvurmuş ve vasî kararının iptalini istemiştir. ${ }^{20}$

Tüm bu dava sonucunda 43 nefer kişinin şahitliğinde babanın rüşd talebi onaylanmıştır.

Rüşd ispatı davaları içerisinde son dava defterin 45 numaralı sayfasında yer alan 1. davadır. Davayı ilginç kılan noktalardan bir tanesi baba tarafından ölümünün gerçekleşmesi halinde mallarının oğlu tarafından düşüncesiz bir şekilde kullanılarak zayi edileceği endişesiyle vasî talebi sonrası vasî atandığını fakat zamanla vasî atanmış evlad Mustafa Remzi Efendi tarafından bu anlayışın yanlış olduğu kendisinin rüşd ve güvenilir birisi olduğunu ispatlayabilmek böylece vasî tayininin iptali için mahkemeye başvurduğunu görmekteyiz.

Dava sonucunda altmış sekiz nefer kişi eşliğinde rüşd ispatı sağlanmıştır.

Rüşd ispatı ve rüşd ispatına bağlı olarak vasî talebinin reddi ile ilgili davalarda dikkat çekici unsur talebin onay alabilmesi için çok fazla şahide ihtiyaç duyulduğunun görülmesidir. Örneğin 18 numaralı sayfanın 1. davasında yer alan rüşd ispatında kırk üç şahid “...nâm kırk üç nefer kesân şehâdetleriyle..." ${ }^{21} 45$ numaralı sayfanın 1. davasında ise altmış sekiz nefer kişi ile rüşd onayının verildiğini görmekteyiz. “...nâm altmış sekiz nefer kimesneler li-ecli'ş-şehâde meclis-i şerca hâzirûn olub istişhâd olunduklarında..."22 Böyle bir ihtiyaç nedeni davalar içerisinde yer almamakla birlikte büyük olasılıkla mahkeme

\footnotetext{
20 “...olub malını bi-gayri vech itlaf ve izâ'a eder deyu i'lâm-ı mezkûr derûnunda esâmîsi muharrer müslimînin huzûr-ı şer'inde muvâcehesinde ben tasarrufâtdan hicr ve emvâlimi hıfz ve ümûrumuzu tesviye ve rü'yete derûn-ı i'lâmda ismi muharrer sulbi kebîr oğlum mûmâ-ileyh Ahmed Tevfik Efendiyi vasî nasb ve tacyîn etmiş idi el-hâlet-i hâzâ ben kesb-i salâh ile reşîd olub yani malımı muhâfaza husûsunda tekayyüd ederek harâma sarfdan ve tebzîr-i eşrâfdan tevkî edüb ve her vechle ümûrumu bi'z-zât rü’yete kâdir olmamla hicr-i mezkûrun kıbeli şer'den fekk ve ref'iyle tasarrufâta bana izn verilmek murâdımdır deyu..."( Bkz: Anadolu Kazaskerliği ve Sadareti, 122 No'lu Sicil Defteri, 18/1)

${ }^{21}$ Anadolu Kazaskerliği ve Sadareti, 122 No'lu Sicil Defteri, 18/1)

${ }^{22}$ Anadolu Kazaskerliği ve Sadareti, 122 No'lu Sicil Defteri, 45/1.
}

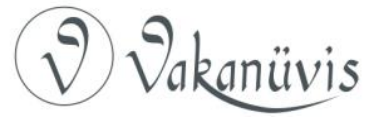


onayı ile belirlenmiş vasî atamalarının çok ince detaylarla belirlenmiş kurallar eşliğinde gerçekleştirilmiş olmasından kaynaklanmaktadır.

\section{b) Ölüm Sonucu Vasî Tayini}

Bu başlık altında inceleyeceğimiz dava sayısı üç olup bunlardan ikisi gemi kazası sonucu ölen kişilerin mirasçılarının belirlenerek vasî tayinini konu almaktadır. Bir davada normal ölüm sonrası vasî tayinidir.

İlk davamı 122 No'lu defterin 82 numaralı sayfasındaki birinci davadır. Bu davada İzmit Sancağına bağlı Kandıra kazası Şile açıklarında bir tayfanın çektirme adı verilen deniz araçlarının Gürcü Kumpanyasına ait Bandırma adlı vapurun kaptanı tarafından üzerlerine sürülmesi, çektirme adı verilen deniz aracının basılması ve tayfanın ölümü ile gerçekleşen olaylar sonucunda mirasçıları arasında mal paylaşımı ve mirasçıların rüşd yaşa gelene dek vasi tayin edilme zorunluluğunu ele almaktadır. Bu davada dikkat çekici noktalardan biri ise bir kaptan tarafından açık denizde bir başka deniz aracının basılmasıyla tayfanın telef edilmesidir. Dava içerisinde bu olayın nedenleri üzerinde durulmamış olup sadece gemi tayfasında bulunup ölen kişilerin ölümlerinin nasıl gerçekleştiği ve mirasçılarının isimleri ve bunlar arasındaki taksimin konu alındığını görmekteyiz. ${ }^{23}$

Ölüm sonrası gerçekleşen vasî tayini davalarının bir örneği 122 No'lu defterde 92 numaralı sayfanın birinci davasıdır. Davada El-hacc Mustafa Efendi adlı kişinin vefat etmesi sonucu eşi (Kamile), Oğlu (Abdullah), Kızı (Cemile) ile ilgili vasi tayini ve alacak davasını konu almaktadır. Anne Kamile'nin ölümü sonrasında çocuklar adına vasi atanır ve vasi, Oğul Abdullah adına annesinin kabz edilen altmış adet tam yüzlük mecidiye altununu talep etmek üzere açılmıştır. ${ }^{24}$

Defterde gemi kazası sonucu vasî tayinini içeren davaların ikinci ve sonuncusu 122 No'lu defterin 100 numaralı sayfasında yer alan birinci davadır. Fakat bir önceki davaya göre bu olay doğal yollarla geminin batması sonucu gerçekleşmiş, sonrasında ise ölen tayfanın çocuklarına miras hakkını ve vasi tayinini içermektedir. Davayı farklı kılan nokta belirlenen vasi tarafından, beş yıllığına, vasiliğe atandığı çocuklara ait

\footnotetext{
${ }^{23}$ Anadolu Kazaskerliği ve Sadareti , 122 No'lu Sicil Defteri, 82/1.

${ }^{24}$ Anadolu Kazaskerliği ve Sadareti , 122 No'lu Sicil Defteri, 92/1.
}

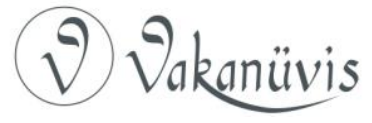


mallar üzerinde işletme hakkını ele almış olmasıdır. Malların kalem kalem tutarları belirlenmiş ve deftere kaydedilmiştir. Bu işlemin çocukların kabulleri çerçevesinde yapıldığı ifadesine de yer verildiğini görmekteyiz. ${ }^{25}$ Dava bir vasî'nin sınırlarının neler olduğu ile ilgili bilgi vermesi açısından doğrulayıcı niteliktedir. Bir vasî, vasîsi olduğu kişi ya da kişilerin malları üzerinde kendi çıkarlarına yönelik tasarrufta bulunamaz. Mallar üzerinde tasarruf ederek, malları işletme hakkını vasîsi olduğu kişilerin çıkarlarına uygun bir şekilde yapması gerekmekteydi. Tüm bu işlemleri gerçekleştirirken mahkeme kararı ile onay alması zorunluluğunda olan yasal temsilcidir.

\section{c) Mecnunluk Sebebiyle Vasî Tayini}

Osmanlı devleti içerisinde var olan Bimarhaneler vakıflarca desteklenen kurumlar olmanın yanı sıra tedavi gören hastalardan para alınmaz $^{26}$ ve her türlü tedavileri dönemin koşullarına göre sağlanmaya çalışılırdı. Aşağıda takip edeceğiniz iki dava İstanbul'da Üsküdar'da

25 “...meclis-i şerc-i şerîf-i enverde sugâar-ı mezbûrun bâ cem'uhüm mallarını li-ecli'ledâne kıbeli şer'den vasî nasib ve tacyîn olunan muhzır Mehmed Emin Ağa ibn Ahmed mahzarında ikrâr-ı tâm ve takrîr-i kelâm idüb vasî mezbûr Mehmed Emin Ağa suğâr-ı merkûmûndan ancak mezbûrûn Mehmed ve İsmail Hakkı ve Fatma'nın ez-zikr misilli kattu'l-ünseyeyen mallarından bana kırk aded tam yüzlük mecidiye altunu ve sagîrât-ı mezbûrât Zeyneb ve Nazife ve Emine'nin müşterek mallarından yine bana kırk aded tam yüzlük mecidiye altunu ve suğâr-ı mezbûrûn Ahmed ve Hafîz ve ez-zikr misilli kattu'l-ünseyeyn mallarından bana kırk aded tam yüzlük mecidiye altunu ve sugâar-ı mezbûrûn Salih ve İzzet ve Mehmed'in dahi kezâlik müşterek mallarından bana kırk aded tam yüzlük mecidiye altunu bi'l-vesâye edâne ve teslîm eylediğinde ben dahi yedinden istidâne ve kabz ve ümûruma sarfla istihlâk idüb cem‘an yüz altmış aded tam yüzlük mecidiye altunları ile semenî târîh-i vesîkadan beş sene tamâmına değin mü'eccel ve mev'ûd yine sugaâr-ı mezbûrûn Mehmed ve İsmail Hakkı ve Fatma'nın kezâlik li-zikr-i meşrûtu'l-ibneteyn mallarından ve vasî mezbûr Mehmed Emin Ağa yedinden iştirâ ve kabz eylediğim bir halâsî koyun-ı sağmal semeninden yigirmi dört aded tam yüzlük mecidiye altunu ve yine semen-i târîh-i vesîka-i mezkûreden beş sene tamâmına değin mü'eccel ve mev'ûd yine sugâr-ı mezbûrûn Ahmed ve Hâfız ve Feride'nin li-zikr-i meşrûtu'l-ibnneteyn mallarından ve vasî mezbûr Mehmed Emin Ağa yedinden iştirâ ve kabz eylediğim bir helâlî devât semeninden dahi yigirmi dört aded tam yüzlük mecidiye altunu ve yine semen-i târîh-i vesîka-i merkûmeden beş sene nihsına değin mü'eccel yine sagîrât-ı mezbûrât Zeyneb ve Nazife ve Emine'nin kezâlik seviyyen mallarından ve vasî..."(Bkz: Anadolu Kazaskerliği ve Sadareti , 122 No'lu Sicil Defteri, 100/1)

${ }^{26}$ Hüseyin Özgür, "Tanzimat'tan Cumhuriyet'e Halk Sağlığı Hizmetleri", Osmanlı, 5.Cilt, edt. Hasan Celal Güzel, Güler Eren, yeni Türkiye Yayınları, Ankara 1999-2004, s. 117.

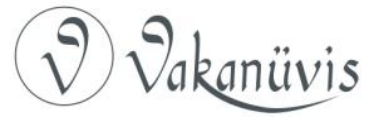


bulunan Bimarhane de geçmektedir. Kuşkusuz bu Bimarhane Üsküdar ilçesine bağlı Atik Valide Külliyesi içerisinde yer alan Toptaşı'dır. Osmanlı tarihi içerisinde çok eleştirilen bir kurum olmasının yanı sıra 1873 sonrası delilerin tecrit edilmesinde bütün imparatorluğa hizmet veren temel müessese olmuş ve bu özelliğini de Cumhuriyet döneminde Bakırköy’ün açılışına kadar sürdürmüştür. ${ }^{27}$

Illk davamız defterimizin 29 numaralı sayfasında yer alan ikinci davadır. Mecnunluk davalarında en dikkat çekici nokta bimarhenelerin varlığı ve Bimarhanelerde bu yönde tedavi verilmesidir. Dava Raşid Efendi'nin sekiz yıldır mecnun olması sebebiyle amcazadesinin vasi olarak tayin edildiğini gösteren belgedir. ${ }^{28}$ Kayıt Üsküdar'da bulunan bimarhanenin varlığına ışık tutmasının yanı sıra davaya sebep olan Mekteb-i Tıbbiye Nazırı tarafından konunun mahkemeye iletilmesidir. Davada babanın varlığından bahsedilmemiştir. Amcanın güvenilir ve ehl bir kimse olduğu şahitlerce dile getirildikten sonra amcazadenin vasi tayin edilmiştir.

Bimarhanelerdeki işleyiş ile ilgili bilgi veren bir diğer davada 122 No'lu defterin 59 numaralı sayfanın birinci davasında yer alan ỉbrahim Şemseddin Efendi'nin Üsküdar'daki bimarhanede üç yıl tedavi görmesi fakat tedavi müddetini aşmış olmasına rağmen herhangi bir iyileşme görülmemesi sebebiyle mal ve mülkünün korunması ve tasarrufu konusunda artık vasi tayininin zorunlu olduğu inanışıyla erkek kardeşi Ahmet Ata Efendi'nin vasi olarak tayin edildiğini gördüğümüz davadır. ${ }^{29}$

Bir mecnunun o dönemdeki tedavi süreci hakkında tam bir bilgiye ulaşamasak da iki dava örneğinden görmekteyiz ki bir mecnunun bir

\footnotetext{
${ }^{27}$ Rüya Kılıç, Deliler ve Doktorları "Osmanlıdan Cumhuriyet'e Delilik, 2. Baskl, Tarih Vakfı Yayınları, İstanbul 2015, s. 54,55.

28 “....bu esnâda li-ecli't-tedâvî Medîne-i Üsküdar'da vâkı ' bîmârhânede sâkin olub ma'rifet-i şer'le mu'âyene olunan mahmiyye-i İstanbul'da Ekşi Karadut kurbünde Oruç Gazi İsmail Ağa Mahallesi ahâlisinden ve asâkir-i şâhâne mülâzimliğinden mütekâ'id Raşid Efendi ibnü'l-müteveffâ Ali bin el-müteveffâ Abdullah sekiz seneden berü mecnûne olub her vechle vasîye muhtâc olduğu hala mekteb-i tıbbiye-i hazret-i şâhâne nâzırı ferîkân-ı kirâmdan sa'âdetlü Abdurrahman Sâib Paşa hazretlerinin işbu bir kıt ${ }^{c} a$ arz-ı hâl-i hâmişinde mestûr i'lâmından müstebân..."(Bkz: Anadolu Kazaskerliği ve Sadareti 122 No'lu Sicil Defteri, 29/2.)

${ }^{29}$ Anadolu Kazaskerliği ve Sadareti 122 No'lu Sicil Defteri, 59/1.
}

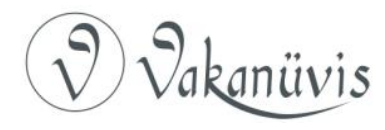


vasîye ihtiyacı olduğu inanışına karar verebilmek için en az üç yıl tedavi edilmesi ve bu süreç sonunda herhangi bir iyileşme belirtisinin görülmemiş olması gerektiğini anlıyoruz.

\section{d) Bakamama Sebebiyle Vasî Tayini}

Osmanlı sosyal yapısı ve işleyişinin çok açık bir şekilde takip edilebildiği defterin 28 numaralı sayfasının birinci davasında yedi yaşlarında olan bir kız çocuğunun annesini kaybetmesi ve babasının maddi kısıtlılıklar nedeniyle O'nunla ilgilenemeyeceği, tek vasisinin kendisi olduğu beyanlarıyla Kamer adlı kadının yanına yardımcı olarak verilmesi kararı alınmıştır. ${ }^{30}$ Benzer davalarda Vasînnin çocuğa yapacağı her bir masraf çocuğun mahkemece belirlenen nafakasından düşmektedir. Aslında nafaka her halükarda babaya aittir fakat baba hem fakir hem de müzmin bir hastalığa tutulup çalışamaz duruma gelmişse, nafaka mükellefiyeti babadan düşmektedir. ${ }^{31}$ Burada anne öldüğü için babanın da bakamama durumunu dile getirilerek çocuk, babanın isteği ve onayı ile Kamer adlı bayanın yanına verilmesinin yanı sıra Kamer adlı kadın vasîsi olarak atanmıştır.

Davanın bir başka önemli yönü o dönemde bir kişinin yanında benzer şartlarda çalışanların ücretleri hakkında bilgi vermesidir. ${ }^{32}$

Vasîlik uygulamasının yalnızca Müslüman çocuklar için söz konusu olmadığını gayrimüslim tebaanın çocukları da aynı haklardan faydalanabilmekteydi. ${ }^{33}$ Fakat anne ya da babadan herhangi birinin Müslüman olması durumunda çocuğunda Müslüman olan ebeveyne tabi olduğu görülmektedir. Çünkü yetkili vasî ve veli arasında din birliği şartı bir kuraldır. Babanın Müslüman olmadığı annenin Müslüman

\footnotetext{
${ }^{30}$ Anadolu Kazaskerliği ve Sadareti 122 No'lu Sicil Defteri, 28/1.

${ }^{31}$ Ahmet Akgündüz, İslam Hukuku ve Osmanlı Tatbikatı Araştırmaları, İstanbul 2009, s. 301.

${ }^{32}$ Şevket Pamuk, Osmanlı Devleti'nde Para'nın Tarihi, Tarih Vakfı Yurt Yayınları, istanbul 2012, 208.

"1844 yılı Tashih-i Sikke işlemiyle 100 gümüş kuruş 1 altın liraya eşit olarak kabul edilmiştir. Bu tarihten sonra altın ve gümüş 15,09 üzerinden birbirlerine bağlanmış ve değişime uğramamıştır. 1870 Gümüş guruş $\operatorname{gr}(1,2)$, ayar $(83,3)$, saf gümüş içeriği ( 1,0), sterline karşı kur (110 kuruş)'tur." Bkz: Pamuk, a.g.e., s.208.

${ }^{33}$ Nesimi Yazıcı, Osmanlı'da Yetimlerin Korunması Üzerine Bazı Değerlendirmeler, Ankara Üniversitesi Illahiyat Fakultesi Yayınları, Sayı:I, Ankara 2007,S.14.
}

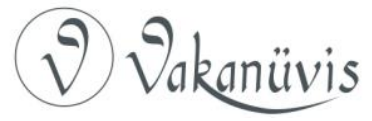


olduğu ebeveynlerde annenin ölmesi durumunda vasîlik annenin Müslüman akrabalarından devam etmekteydi. ${ }^{34}$

\section{e) Vasî Değişimi}

Vasî davaları içerisinde tek gayr-i müslim tebaadan Rum cemaate ait dava olması bakımından defterin 38 numaralı sayfasındaki ikinci dava dikkat çekicidir. Bu davada baba Yavli 80 yaşını geçmiş olmasından dolayı oğlu Paveli'nin vasî olarak atandığını fakat Paveli'nin babasının malları üzerinde gereksiz tüketimde bulunduğu, israfta bulunduğu gerekçesi ile kız kardeş Eleni tarafından babalarına ehl bir kimsenin vasî olarak tayin edilmesini konu alan davadır. ${ }^{35}$

Dava Osmanlı toplumu içerisinde kadın ve kadınların hak arama mücadelesinin sınırlarını göstermesi açısından önemlidir. Osmanlı toplumunda kadın istediği vakit mahkemeye başvurabilir, erkeklerle aynı gün mahkemede yer alabilir hatta bir kadını bir başka kadın savunabilme ${ }^{36}$ kteydi. Osmanlı Devleti bu uygulama ile diğer Müslüman devletlerden ayrılmaktadır.

\section{Vasîlik ile ilgili Problemler}

İncelediğimiz davalarda vasîlik ile ilgili en dikkat çekici nokta vasî tayinlerinde sürenin belirtilmemiş olmasıdır. Süre olarak akil, baliğ ve rüşd tabiri kullanılmış ya da bir yaş sınırı belirtilmiş olup bu süre geldiğinde vasiliğin otomatik olarak düşmediği ve vasîsi bulunan kişi tarafından mahkemeye başvuru yapılarak ispata gitmesi gerektiğini anlıyoruz. İspat aşamasında ise diğer davalarla kıyaslanmayacak şahitle gerçekleştirildiğini görüyoruz. Rüşd ispatı ile açılmış, vasîliğin düşürülmesi ile ilgili iki davanın birinde 68 nefer kişi diğerinde ise 43 nefer kişi eşliğinde rüşd ispatlanmaya çalışılmıştır. (Bkz. Anadolu Sadareti, 122 No'lu Defter, 45/1)

Yaşa bağlı olarak gerçekleştirilen vasî tayinlerinde problem teşkil eden nokta erkek evladın vasî olarak tayin edildiği davalardır. Bu tür davalarda babanın malları üzerindeki tasarruf diğer kardeşler arasında

\footnotetext{
${ }^{34}$ Mehmet Akif Aydın, Osmanlı Aile Hukuku, 1. Basım, Klasik Yayınları, İstanbul 2017, s. 85.

${ }^{35}$ Anadolu Kazaskerliği ve Sadareti 122 No'lu Sicil Defteri, 38/2.

${ }^{36}$ Aydın, a.g.e., s. 102, 103.
}

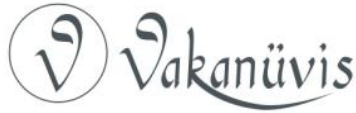


probleme neden olduğunu görmekteyiz. Osmanlı, İslam hukuku çerçevesinde hukuki temsiliyet konusunda erkeğe öncelik tanımış ve vasî seçimlerini bu anlayış ile gerçekleştirmiştir. Fakat dava açabilme, şikâyette bulunabilme anlamında böyle bir öncelik söz konusu değildir. Babasına erkek kardeşi vasî olarak atanmış bir kız evladın erkek kardeşinin babasının malları üzerinde savurganlık ve babasının tasarrufunu zayi edeceği endişesiyle vasî değişimi için mahkeme başvurusu üzerine vasî’nin değişim talebi üzerine talebin onaylandığını görüyoruz. (Bkz. Anadolu Kazaskerliği ve Sadareti, 122 No'lu Defter, $38 / 2$ )

Vasî tayinlerinde baba, dede ve eğer bunlardan biri yoksa kadı́nın atayacağı kişi vasî olarak tayin edilirdi. Osmanlı uygulamalarında babanın olmadığı durumlarda çoğu kez annenin de vasî olarak belirlendiğini görmekteyiz. ${ }^{37}$ Eğer bunlar dışında vasî tayin edilecekse bu kesinlikle kadı'nın hükmünü gerektiren bir durumdur. Vasîlik ile ilgili her türlü konu mahkemece belirlenmek zorundaydı. Yukarıdaki sıralama vasî tayini yapıırken vasî belirlemede kullanılan sıralamadır. Fakat vasîlik kan bağını gerektiren bir durum değildir. Vasîlikte aranan özellikler ehil, güvenilir, akil, baliğ, hür, aynı dinden olan bir kimsenin varlığıdır. Bu özellikleri taşımayan kesinlikle vasî olarak tayin edilemezdi. Eğer vasî olarak tayin edilmiş kişi vasîsi olduğu kişinin malları üzerinde kendi çıkarlarına göre tasarrufa kalkışırsa ya da yukardaki şartlardan birini dahi kaybetmesi durumunda mahkeme kararı ile vasilik kararı iptal edilmekteydi.

Bir diğer göze çarpan konu Osmanlı sosyal düzeninin dayandırıldığı temellerden biri devlet -toplum düzeni içerisinde her türlü sağlık, eğitim, yardımlaşma, temizlik vb. konuların birçoğunu vakıflar aracılığıyla gerçekleştirmiş olmasıdır. Devlet bu tür konulara merkez bütçeden herhangi bir harcama yapmamıştır. Davalar içerisinde de annesinin ölmesi ve babasının bakamayacak olması sebepleriyle yedi yaşında bir kız çocuğunun varlıklı bir kadının yanına nafaka şartlarının belirlenmesi ile O'nun bakımı ve hizmeti ile ilgilenmek şartıyla kadının vasîsi olarak tayin edildiğini görmekteyiz. (Bkz. Anadolu Kazaskerliği ve Sadareti, 122 No'lu defter, 28/1) Devlet bu tür çocukların bakımını bizzat üstlenmemiş ve toplumsal düzen içerisinde bu tarz

${ }^{37}$ Aydın, Türk Hukuk Tarihi, s.223.

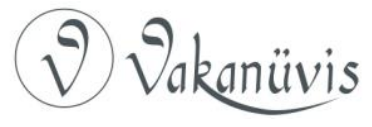


uygulamalarla hem bakımlarını idame etmelerini hem de hukuksal anlamda haklarını koruma altına almış olduğunu görüyoruz.

\section{Sonuç}

$\mathrm{Bu}$ çalışma çerçevesinde ele alınan konular Anadolu sadareti'ne bağlı 122 No'lu Şer'iyye Sicil Kaydı içerisindeki vasî konulu kayıtlardır. 122 No'lu bu defter bir hüccet kaydıdır. Hüccet defterlerinin görülen davaların birer kaydının yapıldığı defterler olması bakımından işlevlerini bugün ki noterlere benzetebiliriz.

Vasî tayinlerinin yapılmasında en önemli nokta hukuksal anlamda temsil kabiliyetlerini kazanmamış çocuk ya da temsil kabiliyetlerini kaybetmiş kişilerin ihtiyarlık ya da mecnunluk gibi nedenlerden dolayı hukuksal temsiliyetlerinde ya da hukukla ilgili işlerin devam ettirilebilmesi için ortaya çıkmış bir çözüm yoludur. Bu amaçla atanan kişiler atandıkları kişinin velayet hakkına sahip olmamakla birlikte vesayet hakkına sahip olurlar. Böyle bir ayrıma neden başvurulduğu konusuna gelince velayet hakkı birey üzerinde tam yetkili olabilmeyi ve O'nun malları üzerinde tam tasarruf hakkını ifade etmektedir fakat vesayet bir tür sınırlama çizmiştir. Vasî olarak tayin edilen kişi vasi tayin edildiği kişinin hukuki temsilcisidir fakat onun ve onun malları üzerinde sınırsız bir tasarruf hakkına sahip değildir. Vasî olarak atanan kişi, vasîsi üzerinde yapacağı her türlü hukuksuz işlem denetime tabidir. Kendi adına hiçbir tasarrufta bulunamaz yalnız vasî olarak atandığı kişinin onayı ve O'na tasarruf kazandırmak amacıyla mahkemece tasarruf ettireceği mal-mülk üzerindeki şartların kayıt altına alınmasından sonra böyle bir işletme prensibi uygulayabilirdi. Fakat vasî, hidane masraflarını kendi cebinden ödemez bunu vasîsi olduğu kişi ya da kişilerin gelirlerinden karşılamaktaydı.

Vasî olarak baba, dede ve bu ikisi yok ise kadı vasî belirleme hakkına sahiptir. Vasî olarak atanacak kişiler arasında ilk olarak baba, ikinci olarak dede gelmektedir. Çoğu kez annenin de vasî olarak tayin edildiğini de görmekteyiz. Eğer bunlar arasından bir atama yapılmayıp kadı tarafından atama yapılmışsa hiçbir şekilde kan bağı olmayan hür, ehil, akil, bülûğa ermiş, güvenilir ve aynı dinden bir kişi Vasî olarak tayin edilmekteydi. Eğer vasî bu şartlardan birini dahi kaybederse vasilliğin iptali gerçekleştirilir fakat bu karar yine kadı tarafından gerçekleştirilirdi.

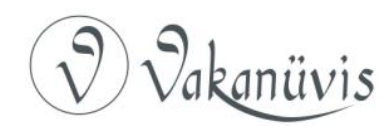


İncelediğimiz çalışmamızda vasî tayinlerini zorunlu kılan nedenler arasında; çocuk olma - rüşd olmama, yaşa bağlı ihtiyarlık, mecnunluk gibi sebepler yer almaktadır.

Vasî tayinleri içerisinde süre belirlenmemiştir. Fakat vasî değişmez gibi bir durum söz konusu değildir. Herhangi bir nedenle mahkemeye şikâyette bulunulması ve şikâyet haklılı̆ı ispatlandığı durumlarda vasî değişim taleplerinin onaylandı̆̆ını görmekteyiz.

Vasî değişimleri için şikâyet talepleri haksız tasarruf, savurganlık ya da rüşd ispatı nedeniyle yapılmıştır. Rüşd ispatı ile gerçekleşen başvuru taleplerinde, mahkeme kararının çok sayıda şahit ile sonuçlandırıldığı görülmektedir. Mahkemenin böyle bir yol izlenmesinin altında yatan etken mahkeme kararı ile ince detaylarla belirlenmiş vasî tayininin iptal gerekçelerinin doğruluğu sorgulanmış olmasındandır.

Kayıtlardan takip ettiğimiz kadarıyla Vasî olarak belirlenen kişilerin bir ücret alıp almadıkları bilinmemekle birlikte bu tür bir bilgi dava tutanaklarında da yer almamaktadır. Vasî olarak atanan kişi vasîsi olduğu yetimlerin, yaşlıların, mecnunların malları üzerinde onlar adına tasarrufta bulunabilir fakat bu uygulamanın sınırları mahkemece belirlenmek zorundadır. Yalnızca hidane masrafları için yaptığı harcamaları vasî, vasîsi olduğu kişi/kişilerin tasarruf mallarından düşme hakkına sahipti.

Incelenen davalar içerisinde en çarpıcı noktalardan bir tanesi Osmanlı sosyal düzeni içerisinde Bimarhanelerin varlığı ve burada mecnunluk kapsamında tedavi gören kişilerin durum değerlendirmelerinin yapılarak kurumlar arası yazışmalar aracılığıyla ilgili birimlere kişi hakkında bilgi verilmesidir. Böylece ehliyet hakkına sahip olmayan kişilerin hakları ve tasarrufları koruma altına alınmış olmakla birlikte onların maddi ve manevi olarak zarar görmesi engellenmeye çalışılmıştır.

Tüm kayıtlar Osmanlı toplumsal yapısı, Osmanlı Hukuk yapısı hakkında önemli bilgiler ihtiva etmekle birlikte günümüzdeki davalara dahi ışık tutmaktadır. Bugün ki yerleşim alanları ve bu alanlar üzerinde yaşayan ailelerin devamlıı̆ı̆ın takibi yapılabilmesi açısından açık, anlaşılır bilgilere sahip olması bakımından günümüzde değerlendirilebilecek bilgiler ihtiva eden kayıtlardır.

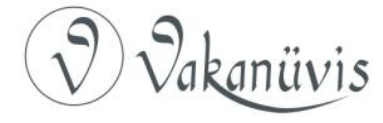




\section{Kaynakça}

Abacı, Nurcan, Bursa Şehri'nde Osmanlı Hukuku'nun Uygulanması ( 17. Yüzyıl), T.C. Kültür Bakanlığı Yayınları, Ankara 2001.

Akgündüz, Ahmet, İslam Hukuku ve Osmanlı Tatbikatı Araştırmaları, Osmanlı Araştırmaları Vakfı Yayınları, İstanbul 2009.

Anadolu Kazaskerliği ve Sadareti, 122 No'lu Şer'iyye Sicil Defteri.

Argıt, Betül İşpirli, "Osmanlı Hukuk Çalışmaları'nda Kadın", Türkiye Araştırmaları Literatür Dergisi, Cilt:3, Sayı:5, 2005, s. 577.

Arsali Sadri Maksudi, Türk Hukuk Tarihi, Türk Tarih Kurumu Yayınları, Ankara 2014.

Aydın, M. Akif, Türk Hukuk Tarihi, Beta Yayınları, İstanbul 2015.

Aydın, M. Akif, Osmanlı Aile Hukuku, Klasik Yayınları, İstanbul 2017.

Bağdatlı, Selahattin, "Kişi”, Hukuk Sözlüğü, Derin Yayınları, İstanbul 2012, s. 395.

Ekinci, Ekrem Buğra, İslam Hukuku "Umumi ve Hususi Hükümler", Arı Sanat Yayınları, İstanbul 2016.

Ekinci, Ekrem Buğra, Osmanlı Hukuku "Adalet ve Mülk", Arı Sanat Yayınları, İstanbul 2017.

Kayhan, Şaban, Hukukun Temel Kavramları, Seçkin Yayınları, Ankara 2011.

Kılıç, Rüya, Deliler ve Doktorları "Osmanlıdan Cumhuriyet'e Delilik, Tarih Vakfı Yayınları, İstanbul 2015.

Özcan, Azmi vd, "Hüccet", İslam Ansiklopedisi, C.18, Diyanet Vakfı Yayınları, İstanbul 1998 , s. 446.

Özcan, Azmi vd, "Vesayet", Islam Ansiklopedisi, C. 43, Diyanet Vakfı Yayınları, İstanbul 1998, s. 67.

Özcan, Tahsin, Osmanlı Toplumu'nda Yetimlerin Himayesi ve Eytam Sandıkları, iü illahiyat Fakultesi Yayınları, İstanbul 2006.

Özgür, Hüseyin, "Tanzimat'tan Cumhuriyet'e Halk Sağlığı Hizmetleri", Osmanlı, 5.Cilt, (edt. Hasan Celal Güzel, Güler Eren,) Yeni Türkiye Yayınları, Ankara 1999-2004, s. 117.

Pamuk, Şevket, Osmanlı Devleti'nde Para'nın Tarihi, Tarih Vakfı Yurt Yayınları, İstanbul 2012.

Yazıcı, Nesimi, Osmanlı'da Yetimlerin Korunması Üzerine Bazı Değerlendirmeler, Ankara Üniversitesi Illahiyat Fakultesi Yayınları, Sayı:I, Ankara 2007.

Yılmaz, Fehmi, "Vasî", Osmanlı Tarihi Sözlüğü, Gökkubbe Yayınları, İstanbul: 2010, s. 680.

Yücel, Hasan, "Osmanlı Devleti'nde Vakıflar ve Kadın (16. ve 17. Yüzyıllar)", Osmanlı, (Edt: Hasan Celal Güzel, Güler Eren), Yeni Türkiye Yayınları, Ankara 1999-2004, s. 49.

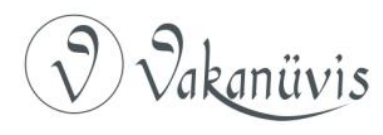

